\title{
Initial improvement of a sewage system after embankment: a combined index of water and sediment quality
}

\author{
N. T. Thuong ${ }^{1,2}$, M. Yoneda ${ }^{1}$ \& Y. Matsui ${ }^{1}$ \\ ${ }^{1}$ Department of Environmental Engineering, Kyoto University, Japan \\ ${ }^{2}$ Vietnam Institute of Architecture, Urban and Rural Planning, Vietnam
}

\begin{abstract}
To Lich River (TLR) system receives wastewaters from a population of nearly two million people and 99 manufacturers of five industrial zones in inner city Hanoi, Vietnam. To improve quality of TLR, the construction of an embankment has been carried out during the period 1998-2002. Water and sediment quality indices based on heavy metal concentrations were used to evaluate the current river environment compared to that of the pre-embankment. The mass balance model was employed to estimate total metal loads for specific river reaches, which correspond to various types of wastewater discharged along the river. The results indicated that domestic-discharged river reaches received much lower metal loads, roughly 8-28\% compared to river reaches of both domestic and industrial inputs. Total load of all nine concerned metals (Cr, Mn, Fe, $\mathrm{Ni} \mathrm{Cu}, \mathrm{Zn}$, $\mathrm{As}, \mathrm{Cd}$, and $\mathrm{Pb}$ ) at the end of TLR is $161.7 \mathrm{~kg} /$ day. Water quality was improved after completion of the embankment, then it gradually deteriorated. Meanwhile, sediment quality became much worse after the embankment. Relative river quality index as an equal weight for both water and sediment quality indices indicated that quality of TLR was not much improved after the embankment. It even became worse due to urbanization in recent years. To improve quality of a sewage system, the embankment is not enough and is just an initial stage. The next stage which may become more important is a treatment plan to fully treat wastewater at sources following environmental standards before discharging to a sewage system.
\end{abstract}

Keywords: mass balance, metal load, sediment accumulation, river quality index, industrial discharge. 


\section{Introduction}

Water bodies in a city such as rivers, canals, lakes, and reservoirs are usually serving as discharging wastewaters. The health of a water body is much dependent on quality of discharged waters to its body. Pollution is facilitated in several respects in urban basins. First, un- and/or partially treated wastewater from both industry and municipality is discharged directly to sewage system. Second, construction activities generate a number of pollutants that easily adsorb or dissolve in runoff. Third, high background pollution loads often accumulate in urban areas between rainy events, mostly from structural deterioration and/or improper disposals of solid waste of industry and municipality, and others. The pollution loads often adversely affect water and sediment quality, and biological communities [1, 2].

Sedimentation is a natural process and represents a fundamental part of ecosystem functioning that is essential to the health water bodies [3]. Many human activities such as manufacturing, construction, and transportation dramatically increase the rate of erosion, resulting in larger than normal sediment deposits with various organic and heavy metal contaminants. Sediment load from construction can be 10 to 20 times greater than cultivated lands [4] and it often exceeds the natural assimilative and equilibrating capacities of the receiving water bodies. The contaminants of most concern are metals, polyaromatic hydrocarbons, polychlorinated biphenyls, and mineral oil. Therefore, disposal of polluted dredged sediments on land may lead to certain risks. Dredging is necessary to increase water flow rate, but also for remediation, whereas the risk for the environment and health might be high. Currently, contaminated dredged sediment is often not valorisable due to its high contaminant content and its consequent hazardous properties. Organics can be destroyed in place, whereas metals are immutable and relatively immobile.

This study aims at (1) evaluating contamination levels of sediment and water, and quality of To Lich River (TLR) 9 years after completion of the embankment, and (2) estimating daily discharge of total organic carbon and heavy metals at the end of TLR.

\section{Materials and methods}

\subsection{Study site}

There are four main rivers forming To Lich River (TLR) system, which receives wastewaters from inner city of Hanoi and covers a basin area of $77.5 \mathrm{~km}^{2}$ [5]. To Lich is the biggest river receiving wastewaters from western part of Hanoi, while Kim Nguu, Set and Lu are three smaller ones receiving wastewaters from eastern part before discharging to TLR in downstream (Figure 1). TLR originates from West Lake, receiving mainly domestic wastewater upstream and a mix of domestic and industrial wastewater downstream before joining Nhue River through Thanh Liet Dam (Figure 1). The construction of the embankment was completed in 2002, covering most of the river reaches. Currently, the embanked 
river reaches have a width of 20-45 $\mathrm{m}$ and a depth of 2-4 m, and a maximum flow capacity of $30 \mathrm{~m}^{3} / \mathrm{s}$. In the dry season, water released from West Lake is limited because of low water level. The input flow then is mainly wastewaters from households and industry with high contaminants [6].

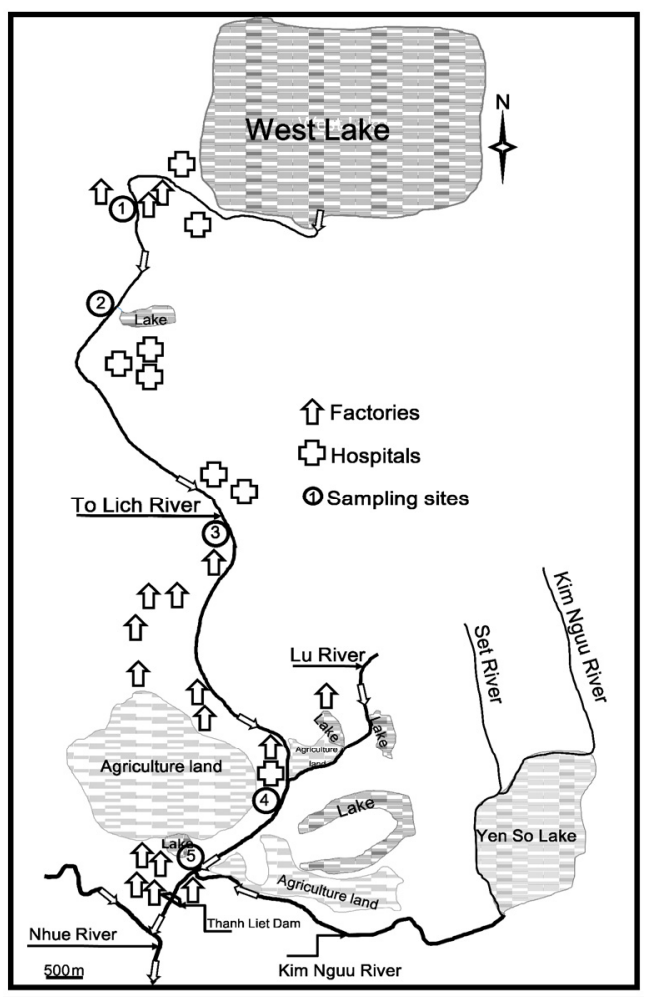

Figure 1: $\quad$ Map of study area showing sampling positions.

There are five industrial zones located in TLR system basin, in which no suitable wastewater treatment systems are available [5]. Thuong Dinh industrial zone consists of 30 manufacturing plants, which have been directly discharging un- and/or partially treated wastewater to downstream reach of TLR. Other four industrial zones, including 69 plants of all types of industries, discharge wastewaters to Lu, Set, and Kim Nguu rivers, before entering TLR downstream (Figure 1).

To control the water flow direction of TLR, Thanh Liet Dam was built at 0.5 $\mathrm{km}$ downstream (Figure 1). The dam is closed when the water level of TLR is lower than that of Nhue River and/or TLR water is too polluted, which may affect the agricultural production downstream of Nhue River. In such cases, water runs to Yen So Lake through the downstream reach of Kim Nguu River and then it is forcedly pumped to the Red river. 


\subsection{Sample collection}

Sediment of 0-30, 30-60, 60-90 and 90-120 cm depths, and surface water were collected at five positions along TLR (Figure 1). The first and second sampling positions were located in embanked river reach, receiving most domestic and hospital wastewater. The third sampling position was located right before discharge of Thuong Dinh industrial zone. The fourth and fifth samplings were located in un-embanked river reach, after confluence with Lu and Kim Nguu rivers, respectively. All samples were collected in the dry season in March 4-5, 2011.

Water samples were collected in pre-cleaned polypropylene bottles and preserved at $4^{\circ} \mathrm{C}$ in refrigerator until analysis. The $\mathrm{pH}$ of water was measured insitu using a portable $\mathrm{pH}$ meter, while heavy metals were determined by acidifying the water samples with conc. $\mathrm{HNO}_{3}$ to $\mathrm{pH}<2$. Sediment samples were taken by using a self-made sediment sampler and placed into polyethylene bottles.

\subsection{Chemical analysis}

Total organic carbon (TOC) contents in water and sediment were analyzed using a TOC analyzer (TOC-5000A, Shimadzu). After collecting sediment samples were air-dried at room temperature and passed through $1 \mathrm{~mm}$ stainless steel sieve to remove big particles. Then the samples were heated in an oven at $60^{\circ} \mathrm{C}$ until constant weight, powdered and homogenized. For microwave-assisted acid digestion procedure, roughly $50 \mathrm{mg}$ dry sediment was weighed into a vessel and successively digested with $10 \mathrm{~mL}$ of conc. $\mathrm{HNO}_{3}$ in a microwave digestion system [7]. After cooling, the digest was transferred into a plastic volumetric flask and adjusted to $50 \mathrm{~mL}$ volume with Mili-Q water. The sample was finally filtered through a membrane filter $(0.45 \mu \mathrm{m}$ pore size $)$. Concentrations of heavy metals (Cr, Mn, Fe, Ni, Cu, Zn, As, Cd, and $\mathrm{Pb}$ ) in both water and sediment were then determined using ICP-MS.

\subsection{Water flow rate}

Water flow (Q; $\mathrm{m}^{3} / \mathrm{s}$ ) at each sampling position was calculated as $\mathrm{Q}=\mathrm{V} \times \mathrm{A}_{\mathrm{w}}$, where $V$ is water velocity $(\mathrm{m} / \mathrm{s})$ and $A_{w}$ is cross-section of water body $\left(\mathrm{m}^{2}\right)$. V was measured using FP101-FP201 Global Flow Probe. Width of water surface, water depth, and slope of river bank at each sampling position were measured to estimate its area of water cross-section by using basic geometry techniques.

\subsection{Loading of heavy metals}

A modified mass-balance model [8] was used to estimate chemical load in a river reach following eqn. (1).

$$
Q_{d} C_{d}-Q_{u} C_{u} e^{-k t}=\sum_{i=1}^{n} L_{i}
$$


where $\mathrm{k}$ is rate of attenuation/decay coefficient $\left(\right.$ day $\left.^{-1}\right), t$ is travel time (day), $Q_{d}$ and $Q_{u}$ are downstream and upstream flows, $C_{d}$ and $C_{u}$ are downstream and upstream concentrations, and $\sum_{\mathrm{i}=1}^{\mathrm{n}} L_{i}$ is the sum of all individual loadings to the river reach.

\subsection{River quality index}

Water quality index has been widely used to evaluate the quality/pollution levels of a water body $[9,10]$. In this study, we extend this knowledge to evaluate quality of both water and sediment as a base for river quality assessment. A water quality index (WQI) and a sediment quality index (SQI) were calculated following eqn. (2):

$$
\begin{gathered}
\text { Index }_{\text {metal }} \text { in water or sediment }=\frac{\text { Concentration metal } \mathrm{i}_{\text {in water or sediment in year A }}}{\text { Concentration metal } \mathrm{i}_{\text {in water or sediment }} \text { in year B }} \\
\text { WQI or SQI }=\left(\sum_{\mathrm{i}=1}^{7 \text { or } 5} \text { Index }_{\text {metal }_{\text {in water or sediment }}}\right) / 7 \text { or } 5
\end{gathered}
$$

Note that $\mathrm{A}>\mathrm{B}$.

Then, a simple relative river quality index (RQI) was derived as eqn. (3):

$$
\mathrm{RQI}=(\mathrm{WQI}+\mathrm{SQI}) / 2
$$

where when WQI, SQI, and/or RQI equals 1 there is no improvement for water, sediment and/or river, while it is improved if the values are $<1$, and becomes worse if the values are $>1$.

\section{Results}

\subsection{Sediment quality}

High variation of total organic carbon (TOC) and heavy metal concentrations among sampling positions was found (e.g. TOC content varied between 11 at S4 and $60 \mathrm{~g} / \mathrm{kg}$ at S3, Cr ranged from 90 at S4 to $229 \mathrm{mg} / \mathrm{kg}$ at S2, Mn ranged from 392 at S1 to 610 at S2, Cd ranged from 1.0 at S1 to $35 \mathrm{mg} / \mathrm{kg}$ at S3). Comparing among heavy metals, the average concentrations in sediment increased following the order of $\mathrm{Cd}<\mathrm{As}<\mathrm{Ni}<\mathrm{Pb}<\mathrm{Cu}<\mathrm{Cr}<\mathrm{Mn}<\mathrm{Zn}<\mathrm{Fe}$ (Table 1 ).

Concentrations of $\mathrm{Zn}$ and $\mathrm{Cd}$ far exceeded the maximum permissible concentrations of potentially toxic heavy metal for crops [11]. Comparing to Vietnamese standard, contents of most concerned heavy metals exceeded the allowable limit for both agricultural and industrial soils (Table 1). 
Table 1: $\quad$ Mean ${ }^{1}$ concentration ( \pm SD) of total organic carbon (TOC; g/kg) and heavy metals $(\mathrm{mg} / \mathrm{kg})$ in sediment.

\begin{tabular}{|c|c|c|c|c|c|c|c|c|c|c|}
\hline $\begin{array}{l}\text { Sampling } \\
\text { position }\end{array}$ & TOC & $\mathrm{Fe}$ & Mn & Zn & $\mathrm{Cr}$ & $\mathrm{Cu}$ & $\mathrm{Pb}$ & $\mathrm{Ni}$ & As & $\mathrm{Cd}$ \\
\hline S1 & $\begin{array}{l}48.3 \\
\pm 7.1\end{array}$ & $\begin{array}{l}13,139 \\
\pm 3,142\end{array}$ & $\begin{array}{l}392 \\
\pm 57\end{array}$ & $\begin{array}{l}513 \\
\pm 73\end{array}$ & $\begin{array}{l}229 \\
\pm 75\end{array}$ & $\begin{array}{l}103 \\
\pm 18\end{array}$ & $\begin{array}{l}75 \\
\pm 15\end{array}$ & $\begin{array}{l}51 \\
\pm 6\end{array}$ & $\begin{array}{l}21 \\
\pm 4\end{array}$ & $\begin{array}{l}1.0 \\
\pm 0.2\end{array}$ \\
\hline S2 & $\begin{array}{l}33.5 \\
\pm 3.0\end{array}$ & $\begin{array}{l}21,718 \\
\pm 4820\end{array}$ & $\begin{array}{l}610 \\
\pm 92\end{array}$ & $\begin{array}{l}770 \\
\pm 82\end{array}$ & $\begin{array}{l}144 \\
\pm 36\end{array}$ & $\begin{array}{l}146 \\
\pm 12\end{array}$ & $\begin{array}{l}90 \\
\pm 10\end{array}$ & $\begin{array}{l}77 \\
\pm 12\end{array}$ & $\begin{array}{l}24 \\
\pm 3\end{array}$ & $\begin{array}{l}2.3 \\
\pm 0.3\end{array}$ \\
\hline S3 & $\begin{array}{l}60.8 \\
\pm 15.3\end{array}$ & $\begin{array}{l}16,783 \\
\pm 5,308\end{array}$ & $\begin{array}{l}438 \\
\pm 121\end{array}$ & $\begin{array}{l}783 \\
\pm 301\end{array}$ & $\begin{array}{l}128 \\
\pm 36\end{array}$ & $\begin{array}{l}139 \\
\pm 50\end{array}$ & $\begin{array}{l}92 \\
\pm 27\end{array}$ & $\begin{array}{l}98 \\
\pm 17\end{array}$ & $\begin{array}{l}28 \\
\pm 13\end{array}$ & $\begin{array}{l}35.3 \\
\pm 47.0\end{array}$ \\
\hline S4 & $\begin{array}{l}11.7 \\
\pm 7.6\end{array}$ & $\begin{array}{l}22,442 \\
\pm 2,373\end{array}$ & $\begin{array}{l}572 \\
\pm 53\end{array}$ & $\begin{array}{l}255 \\
\pm 137\end{array}$ & $\begin{array}{l}90 \\
\pm 24\end{array}$ & $\begin{array}{l}57 \\
\pm 21\end{array}$ & $\begin{array}{l}58 \\
\pm 14\end{array}$ & $\begin{array}{l}68 \\
\pm 21\end{array}$ & $\begin{array}{l}16 \\
\pm 4\end{array}$ & $\begin{array}{l}4.0 \\
\pm 4.9\end{array}$ \\
\hline S5 & $\begin{array}{r}19.5 \\
\pm 3.5 \\
\end{array}$ & $\begin{array}{l}21,585 \\
\pm 384\end{array}$ & $\begin{array}{l}538 \\
\pm 50 \\
\end{array}$ & $\begin{array}{l}412 \\
\pm 78 \\
\end{array}$ & $\begin{array}{l}132 \\
\pm 34\end{array}$ & $\begin{array}{l}74 \\
\pm 11\end{array}$ & $\begin{array}{l}63 \\
\pm 8 \\
\end{array}$ & $\begin{array}{l}70 \\
\pm 10\end{array}$ & $\begin{array}{l}23 \\
\pm 4\end{array}$ & $\begin{array}{l}13.2 \\
\pm 1.9 \\
\end{array}$ \\
\hline $\begin{array}{l}\text { QCVN } 03 \\
\text { for } \\
\text { agricultural } \\
\text { soil }\end{array}$ & - & - & - & 200 & - & 50 & 70 & - & 12 & 2 \\
\hline $\begin{array}{l}\text { QCVN } 03 \\
\text { for } \\
\text { industrial } \\
\text { soil }\end{array}$ & - & - & - & 300 & - & 100 & 300 & - & 12 & 10 \\
\hline MCC $^{2}$ & - & - & - & 450 & 400 & 200 & 300 & 110 & & 3 \\
\hline
\end{tabular}

${ }^{1}$ Mean of all sediment layers in each sampling position, QCVN 03 -Vietnamese standards of heavy metals in soils, ${ }^{2}$ maximum permissible concentrations for crops [11].

\subsection{Water quality}

There was not much variation in $\mathrm{pH}$, ranging around 7.2-7.3 among sampling positions. Meanwhile, high variation was observed for total organic carbon, the highest value found in S2 of $8.3 \mathrm{mg} / \mathrm{L}$ nearly doubled that in S1 $(4.7 \mathrm{mg} / \mathrm{L})$. Concentrations of $\mathrm{Cr}, \mathrm{Ni}, \mathrm{Cu}$, and $\mathrm{Pb}$ were lower than $10 \mu \mathrm{g} / \mathrm{L}$ and not much different among all sampling positions. Meanwhile, that of $\mathrm{Zn}, \mathrm{As}$, and $\mathrm{Mn}$ were much higher, ranging from 36 to 60, 13-76, and 83-400 $\mu \mathrm{g} / \mathrm{L}$, respectively. Water is not under pollution by heavy metals except Mn (Table 2).

Total loads of TOC and heavy metal generated to each river reach and at the end of To Lich River (TLR) are shown in Table 3). High variation among river reaches was found, e.g. ranging from 338 to 2,036 kg/day for TOC, 0.07-1.35 for Cr, $0.18-2.04$ for $\mathrm{Ni}, 1.25-15.19$ for $\mathrm{Zn}, 3.16-10.49$ for As, from 0.24 to 3.42 $\mathrm{kg} /$ day for $\mathrm{Pb}$. In general, river reaches of S1-S2 and S2-S3 in upstream, where mostly received domestic wastewater, had lower loads compared to that of S3-S4 and S4-S5 river reaches in downstream, which received various types of wastewater. TOC discharged from TLR to Nhue River reached 4,504 kg/day, 
while that of heavy metals was $1.1 \mathrm{~kg} /$ day for $\mathrm{Cr}, 2.3$ for $\mathrm{Cu}, 4$ for Ni, 5.8 for $\mathrm{Pb}$, 16.2 for Zn, 16.2 for As, and up to116 kg/day for Mn (Table 3).

Table 2: $\quad \mathrm{pH}$ value, concentration of total organic carbon (TOC; mg/L) and heavy metals $(\mu \mathrm{g} / \mathrm{L})$ in water.

\begin{tabular}{lllllllllll}
\hline $\begin{array}{l}\text { Sampling } \\
\text { position }\end{array}$ & $\mathrm{pH}$ & $\mathrm{TOC}$ & $\mathrm{Mn}$ & $\mathrm{Zn}$ & $\mathrm{As}$ & $\mathrm{Ni}$ & $\mathrm{Cu}$ & $\mathrm{Pb}$ & $\mathrm{Cr}$ & $\mathrm{Cd}$ \\
\hline S1 & 7.2 & 4.7 & 83 & 58 & 47 & 5 & 5 & 8 & 2 & - \\
S2 & 7.3 & 8.3 & 400 & 40 & 76 & 5 & 4 & 7 & 2 & - \\
S3 & 7.2 & 7.7 & 230 & 36 & 13 & 8 & 3 & 6 & 2 & - \\
S4 & 7.3 & 8.1 & 188 & 60 & 38 & 9 & 7 & 8 & 5 & - \\
S5 & 7.2 & 7.8 & 200 & 28 & 28 & 7 & 4 & 10 & 2 & - \\
\hline IWS $^{1}$ & $6.5-8$ & - & 200 & 2,000 & 100 & 200 & 200 & 5,000 & 100 & 10 \\
\hline
\end{tabular}

${ }^{1}$ Irrigation water standard [12].

Table 3: Total heavy metal and total organic carbon (TOC) discharged to specific river reaches $(\mathrm{kg} / \mathrm{day})$ and at the end of TLR.

\begin{tabular}{llllll}
\hline & River reach & & & & $\begin{array}{l}{ }^{1} \text { Load at } \\
\text { the end of } \\
\text { TLR }\end{array}$ \\
\cline { 2 - 6 } & S1-S2 & S2-S3 & S3-S4 & S4-S5 & 4,504 \\
\hline TOC & 338 & 360 & 1,697 & 2,036 & 116.0 \\
$\mathrm{Mn}$ & 18.55 & 3.25 & 34.40 & 58.51 & 16.2 \\
$\mathrm{As}$ & 3.16 & & 10.49 & 5.01 & 16.2 \\
$\mathrm{Zn}$ & 1.25 & 2.07 & 15.19 & & 5.8 \\
$\mathrm{~Pb}$ & 0.24 & 0.32 & 1.91 & 3.42 & 4.0 \\
$\mathrm{Ni}$ & 0.18 & 0.60 & 2.04 & 1.40 & 2.3 \\
$\mathrm{Cu}$ & 0.14 & 0.15 & 1.88 & 0.27 & 1.1 \\
$\mathrm{Cr}$ & 0.07 & 0.12 & 1.35 & & \\
\hline
\end{tabular}

Estimated values of $\mathrm{Cr}$ and $\mathrm{Zn}$ in S4-S5 river reach and of As in S2-S3 river reach were negative, they were excluded. ${ }^{1}$ Equal to $Q_{d} \times C_{d}\left(Q_{d}\right.$ and $C_{d}$ are downstream water discharge and concentration, respectively).

\subsection{River quality}

Figure 2 shows values of water, sediment, and river quality indices of To Lich River (TLR). Water quality was much improved in 2005 and in 2011 compared to pre-embankment as index of pair of 2005-1997 was 0.4 and that of 20111997 was 0.5 . However, quality of water in 2011 became worse than that in 2005. Conversely, sediment quality became worse after embankment indicated by index of 2.5 between 2005-1997 and of 1.8 between 2011-1997. Sediment quality in 2011 was much improved compared to that in 2005, representing by index of 0.63. Combining water and sediment quality indices indicated that river quality was not improved, it even became more polluted as values of river quality index were higher than 1 for all pairs of year comparisons. 


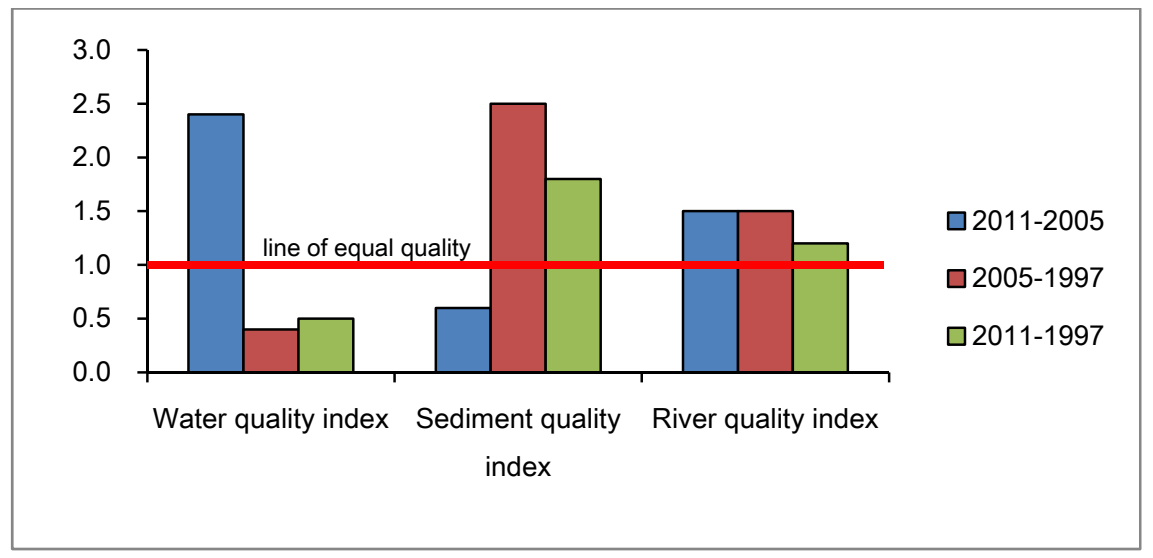

Figure 2: Values of water, sediment, and river quality index. Data of year 1997 were cited from HSDC [13] and that of year 2005 from Kikuchi et al. [14].

\section{Discussion}

It is clear that water of To Lich River (TLR) should be treated prior to irrigation as the $\mathrm{Mn}$ concentration exceeded recommended standard (Table 2). Since wastewaters discharged to river reaches between S1 and S3 were mostly of domestic origin, load of total organic carbon (TOC) and heavy metals were much lower than that in downstream reaches between S3 and S5 (Table 3). This may suggest the responsibility of industry rather than of domestic for metal discharges. Load of $\mathrm{Cr}$ and $\mathrm{Zn}$ in S4-S5 and of As in S2-S3 river reaches were negative (Table 3), which must be always larger than zero. This may suggests that attenuation rate of heavy metals in TLR should be higher than citied values [16] as result of low velocity, higher concentration in water, and others. Taking into account of TOC, which nearly upped to 4.5 tons/day (Table 3) of nutrient contents in water [15], if wastewater is treated properly and reused in agriculture, it may sustain water supply, reduce input costs, and increase crop's productivity and farm income.

Sediment of TLR cannot be directly used for any purposes neither agriculture [11] nor industry (QCVN 03; Table 1). It must be treated following suitable guidelines for specific purpose, even treatment and reuse of heavily contaminated dredged sediments is not a cost-effective alternative to confined disposal [17], which becomes secondary source of contamination. Treatment technologies and experiences have never been put into consideration for sediment of TLR system in Hanoi. This may be the barriers for environmental improvement of TLR.

Discharge of heavy metals and TOC at the end of TLR in 2011 (Table 3) may be underestimate since it was based on water discharge of only 2 investigated days of March 4 and 5 in dry season 2011, when there was no rain. The fact is that dirty on land surface of TLR system basin may contain much organic carbon 
and heavy metals as result of transportation, municipal and industrial solid waste disposals, which all will be discharged to TLR on rainy days.

Water quality index (WQI) showed that quality of water was much improved after embankment (Figure 2) as result of improving flow rate. Because of no suitable wastewater treatment and/or elevated discharge of heavy metals from urbanization, water quality has been becoming worse indicated by increase of WQI to 2.4 between 2011 and 2005. Conversely, it was observed for quality of sediment (Figure 2). The fact is that sediment was almost removed from river bed as preparation for embankment activities, the new layers of sediment were accumulated afterward. Since 2002 after completing embankment, population growth, rapid urbanization, and speed-up of manufacturing activities of industrial zones within TLR system basin led to increasing the amount and pollution level of discharges [5]. However comparing between 2005 and 2011, sediment quality was improved $(\mathrm{SQI}=0.6)$. Probably, pre-physical wastewater treatment was paid much attention by industrial zones as result of issuing environmental regulations recently. The health of a river should be considered in terms of both water and sediment bodies, hence river quality index (RQI) was derived from both WQI and SQI (Figure 2). Quality of TLR has not yet improved since embankment, it even became worse. To improve quality of a river, wastewater should be treated properly before discharging to its body. Meanwhile, the main purpose of TLR embankment was improving water flow rate and reducing solid waste disposal on river banks.

\section{References}

[1] Crawford, K.J. \& Lenat, D.R., Effects of land use on tile water quality and biota of three streams in the Piedmont Province of North Carolina, US Geological Survey, Water Resources Investigations Report 89-4007. Raleigh, North Carolina, 1989.

[2] Mason, C.F., Biology of freshwater pollution. Longman Group Ltd., New York, 1981.

[3] Guy, H.P., Urban sedimentation-in perspective. Proceeding of the American Society of Civil Engineers. Journal of the Hydraulics Division December, pp. 2099-2116, 1972.

[4] Owen, O.S., Natural resource conservation. Mac-Millan, New York, 1975.

[5] Nguyen, V.C., Establishing scientific basics for surface water supplement solution to improve river water quality in Hanoi City. Hanoi Department of Science and Technology. Hanoi, Vietnam, 2005.

[6] Hanoi DONRE., Feasible project on establishing large-scale wastewater treatment plants to improve environment in Hanoi. Hanoi Department of Natural Resources and Environment. Vietnam, 2009.

[7] USEPA., Method 3051A: Microwave assisted acid dissolution of sediments, sludges, soils, and oils. Revision 1. United States Environmental Protection Agency, Washington, DC, 2007. 
[8] Jha, R., Ojha, C.S.P. \& Bhatia, K.K.S., Non-point source pollution estimation using a modified approach. Hydrological Process, 21, pp. 10981105, 2007.

[9] Liou, S.M., Lo, S.L. \& Wang, S.H., A generalized water quality index for Taiwan. Environmental Monitoring and Assessment, 96, pp. 35-52, 2004.

[10] Banerjee, T. \& Srivastava, R.K., Application of water quality index for assessment of surface water quality surrounding integrated industrial estatePantnagar. Water Science and Technology, 60, pp. 2041-2053, 2009.

[11] Steve, P.M., Effect of heavy metals from sewage sludge on soil microbes in agricultural ecosystems. In "Toxic Metals in Soil-Plant System". John Wiley and Sons, Chichester, pp. 247-274, 1994.

[12] WHO., Guidelines for the safe use of wastewater, excreta and greywater: Volume II: Wastewater Use in Agriculture, 2006.

[13] HSDC., Report on improving environmental of To Lich River (stage I). Hanoi Sewerage and Drainage Limited Company, Hanoi, 1997.

[14] Kikuchi, T., Furuichi, T., Hai, H.T. \& Tanaka, S., Assessment of heavy metal pollution in river water of Hanoi, Vietnam using multivariate analyses. Bulletin of Environmental Contamination and Toxicology, 83, pp. 575-582, 2009.

[15] Trinh, A.D., Study of water quality of a urban river hydro system in the periphery of Hanoi (Vietnam); Experiment and modelling. Dissertation. University of Joseph Fourier - Grenoble 1, France, 2003.

[16] Ambrose, R.B., Wool, T., Martin, J.L., Collolly, J.P \&, Schanz, R.W., WASP5X: A Hydrodynamic and Water Quality Model-Model Theory, User's Manual and Programmer's Guide. U.S. Environmental Protection Agency: Athens, GA, 1991.

[17] Bert, V., Seuntjens, P., Dejonghe. W., Lacherez, S., Thuy, H.T.T. \& Vandecasteele, B., Phytoremediation as a management option for contaminated sediments in tidal marshes, flood control areas and dredged sediment landfill sites. Environmental Science Pollution Research, 16, pp. 745-764, 2009. 